\title{
PENERAPAN ASAS KONSENSUALISME DALAM PERJANJIAN JUAL BELI ONLINE
}

\author{
Ni Putu Ayu Bunga Sasmita, Fakultas Hukum Universitas udayana, e-mail: \\ bungasasmita89@gmail.com \\ I Wayan Novy Purwanto, Fakultas Hukum Universitas Udayana, e-mail: \\ novy_purwanto@unud.ac.id
}

doi: https://doi.org/10.24843/KS.2020.v08.i08.p02

\begin{abstract}
ABSTRAK
Penelitian ini bertujuan untuk memahami bagaimanakah pengaturan jual beli online dalam hukum di Indonesia dan bagaimanakah aspek hukum jual beli secara online dalam perjanjian. Penelitian ini, menggunakan metode penelitian hukum normatif. Sedangkan pendekatan yang digunakan adalah menggunakan pendekatan fakta dan statute approach. Hasil penelitian ini menunjukan bahwa pengaturan mengenai jual beli secara online diatur dalam ketentuan Pasal 18 ayat (1) Undang-Undang Republik Indonesia Nomor 19 Tahun 2016 tentang Perubahan Atas Undang-Undang Nomor 11 Tahun 2008 tentang Informasi dan Transaksi Elektronik, yang mana sebagai penerapan pasal 1313 KUHPerdata. Para pihak yang mengadakan perjanjian bisa menerapkan KUHPerdata yang jadi dasar diakui sahnya perjanjian dimana keabsahannya tercantum syarat 1320 KUHPerdata yakni: kecakapan, kesepakatan, suatu sebab yang halal dan suatu hal tertentu.Sedangkan penerapan asas Konsensualisme dalam perjanjian online yang didasarkan oleh ketentuan dalam Pasal 1313 KUHPerdata yang menegaskan bahwa adanya suatu perjanjian berarti pihak satu dengan pihak lainnya setuju untuk mengikatkan dirinya.
\end{abstract}

Kata Kunci: Asas Konsensualisme, Jual Beli Online.

\begin{abstract}
This study aims to understand how the online arrangement in the sale and purchase agreement and how the legal aspects of buying and selling online in the agreement. This research uses normative legal research methods. While the approach used is to use the fact approach and statute approach. The results of this study indicate that the regulation regarding online trading is regulated in the provisions of Article 18 paragraph (1) of the Law of the Republic of Indonesia Number 19 of 2016 concerning Amendment to Law Number 11 of 2008 concerning Information and Electronic Transactions, which is the legal basis for applying article 1313 of the Civil Code. The parties who entered into the agreement can apply the KUHPer which is the basis for the validity of the agreement where the validity is stated in the terms of the 1320 KUHPer, namely: skill, agreement, a halal cause and a certain thing. While the application of the principle of consensualism in an online agreement based on the provisions in Article 1313 of the KUHPer which confirms that an agreement means that one party with another party agrees to bind themselves.
\end{abstract}

\section{Keywords: Consensualism Principle, Buy and Sell Online.}

\section{Pendahuluan}

1.1 Latar Belakang Masalah

Teknologi serta perkembangannya mengakibatkan perubahan pola uaitu terjadinya gaya hidup dan polapikir bermasyarakat pada kehidupan sehari-hari. Dengan demikian, maka teknologi telah mampu merubah orientasi masyarakat. Pemahaman masyarakat dewasa ini lebih cenderung memanfaatkan teknologi dan 
meninggalkan cara konvensional karena teknologi itu efisien dan peraktis. Melihat praktek jual-beli online (e-commerce) yang semakin marak di Indonesia sangat menguntungkan bagi masyarakat selaku konsumen dalam memilih berbagai jenis jasa dan/atau barang namun pelanggaran hak-hak konsumen sangat dimungkinkan terjadi mengingat jual-beli online mempunyai karakteristik yang berbeda dengan transaksi konvensional. ${ }^{1}$ Berkenaan dengan teknologi dan informasi cyberspace dibanyak sektor kehidupan masyarakat telah digunakan. Wiradhipradja dan Budijanto bahwa sistem informasi dan teknologi telah digunakan dibanyak sektor kehidupan, mulai dari perdagangan dan bisnis (electronic commerce/ecommerce) pendidikan (electronic education), kesehatan (tele-medicine), telekarya, transportasi, industri, pariwisata, lingkungan sampai ke sektor hiburan bahkan sekarang timbul pula di bidang pemerintahan (egovernment). Perdagangan saat ini tidak hanya dilaksanakan secara konvensional yaitu secara lisan atau tertulis, melainkan dapat dilaksanakan melalui media online yaitu dengan menggunakan komputer, gadget melalui media internet. ${ }^{2}$ Dimana pada saat ini tidak sedikit masyarakat yang menggunakan media sosial seperti jual-beli secara online. Media sosial merupakan fenomena yang dapat mempermudah aktivitas manusia di era globalisasi ini. Seseorang dapat dengan mudahnya mencari keuntungan melalui akun media sosial milik pribadi. ${ }^{3}$

Di Indonesia transaksi jual beli secara online, selain diatur dalam Kitab Undang-Undang Hukum Perdata (selanjutnya disebut "KUHPerdata"), juga diatur secara spesifik di Undang-Undang Nomor 8 Tahun 2011 tentang Informasi dan Transaksi Elektronik (selanjutnya disebut "UU ITE"). Transaksi secara online seperti halnya transaksi perdagangan pada umumnya adalah merupakan suatu perjanjian antara penjual dan pembeli. Para pihak ini sering disebut merchant dan customer dalam transaksi jual beli secara online, kedudukan merchant dan customer ini sama seperti kedudukan pelaku usaha dalam perdagangan konvensional. Disamping itu, kehadiran e-commerce memberikan kemanjaan yang luar biasa kepada konsumen karena konsumen tidak perlu keluar rumah untuk berbelanja disamping itu pilihan barang atau jasa beragam dengan harga yang relatif murah. Hal ini menjadi tantangan positif dan sekaligus negatif. Dikatakan positif karena kondisi tersebut dapat memberikan manfaat bagi konsumen untuk memilih secara bebas barang atau jasa yang diinginkannya. ${ }^{4}$ Konsumen dalam ini, mempunyai kebebasan, dimana kebebasan yang dimiliki konsumen itu menentukan jenis dan kualitas untuk barang/jasa menyesesuaikan dengan kebutuhan dan hidupnya. Sedangkan, negatifnya karena menyebabkan kondisi tersebut konsumen mempunyai posisi yang lebih lemah dari pelaku usaha, posisi yang dapat mengakibatkan kerugian dan kekecewaan. ${ }^{5}$

Perjanjian antara para pelaku bisnis terjadi pada saat mereka bersepakat untuk melakukan jual beli barang atau jasa yang telah ditawarkan tersebut atau tidak.

1 Mahardika, Putu Surya dan Rudy, Dewa Gede. “Tanggung Jawab Pemilik Toko Online Dalam Jual Beli Online (E-Commerce) Ditinjau Berdasarkan Hukum Perlindungan Konsumen", Kertha Semaya: Journal Ilmu Hukum 02, No.05 (2014): 2-3.

2 Wiradhipradja, E.S dan Budhijanto, D. Perspektif Hukum Internasional tentang Cyber Law, dalam Kantaatmadja, et al, Cyberlaw : Suatu Pengantar (Jakarta, Elips 11, 2002), 88-89.

3 Manika, Ni Putu Mella dan Sukihana, Ida Ayu. "Perlindungan Hukum Terhadap Subjek dalam Potret yang Diunggah ke Akun Media Sosial", Kertha Semaya: Journal Ilmu Hukum 6, No.12 (2018): 10.

4 Wiradipradja, E.S dan Budhijanto, D., Op.cit, h. 92.

5 Susnato, Hapy. Konsumen Hak-Hak Dirugkan, (Yogyakarta, Media Visi, 2008), 2. 
Apabila pembeli atau customer sepakat maka customer harus mentaati peraturan yang sudah dibuat oleh penjual. Pembayaran yang dianggap paling mudah adalah pembayaran yang dilakukan melalui media online karena hanya dengan menentukan barang apa yang diinginkan dari webstore lalu kemudian dapat dibayarkan melalui kartu kredit. Selanjutnya, memasukkan data customer maka pesanan customer segera dalam waktu yang ditentukan diproses.

Sebelumnya telah ada penelitian sejenis yang mengkaji mengenai jual beli online, yaitu Jurnal Kertha Semaya Fakultas Hukum Universitas Udayana dengan judul Penerapan Asas Itikad Baik dalam Perjanjian Jual Beli Online dan Urgensi Kecakapan Dalam Perjanjian Jual Beli Online. Perbedaan penelitian ini dengan penelitian sebelumnya adalah dalam penulisan jurnal ilmiah ini permasalahan yang dikaji adalah mengenai bagaimana penerapan asas konsensualisme dalam perjanjian jual beli secara online. Didasarkan pada latar belakang yang telah diuraikan diatas, penulis tertarik untuk membuat suatu jurnal ilmiah yang berjudul "Penerapan Asas Konsensualisme Dalam Perjanjian Jual Beli Online".

\subsection{Rumusan Masalah}

Berdasarkan latar belakang masalah diatas, dalam tulisan ini dikaji dua permasalahan sebagai berikut:

1. Bagaimanakah pengaturan perjanjian jual beli secara online dalam peraturan hukum di Indonesia?

2. Bagaimanakah penerapan asas konsensualisme dalam perjanjian jual beli secara online?

\subsection{Tujuan Penulisan}

Tujuan dari penelitian hukum pada umumnya adalah untuk memperoleh pengetahuan dari suatu kaeadah hukum dalam sebuah peraturan perundangundangan. Tujuan penulisan jurnal ilmiah ini adalah untuk mengetahui dan memahami pengaturan perjanjian melalui media online dan Penerapan Asas Konsensualisme.

\section{Metode Penelitian}

Penelitian hukum merupakan suatu proses yang ditempuh untuk menemukan guna dapat menjawab isu-isu hukum yang ada. ${ }^{6}$ Pada tulisan ini digunakan metode penelitian normatif dengan menganalisis isu hukum tersebut melalui bahan-bahan buku-buku dan kamus hukum sebagai upaya penyelesaian masalah dari isu hukum. Penelitian ini mengkaji norma-norma atau peraturan perundang-undangan yang mengatur terkait dengan aspek hukum perdata terhadap perjanjian jual beli secara online. Adapun dalam pendekatan yang digunakan penulisan jurnal ini yaitu menggunakan; pendekatan pendekatan analisis konsep hukum (Analitical Conseptual Approach) dan perundang-undangan (Statue Approach). Pendekatan perundangundangan digunakan untuk menganalisa isu-isu hukum dalam penelitian ini yang khusus berhubungan pengaturan perjanjian melalui media online. Pendalaman terhadap bahan hukum yakni menggunakan study dokumens, serta kajian analisis menggunakan kualitatif analisis. Adapun undang-undang yang dipakai mengkaji isuisu hukum tersebut adalah KUH Perdata dan UU ITE.

6 Marzuki, Peter Machmud. Penelitian Hukum (Jakarta, Predana Media Group, 2010), 35. 


\section{Hasil dan Pembahasan}

\subsection{Pengaturan Perjanjian Jual Beli Secara Online Dalam Peraturan Hukum di Indonesia}

Pengaturan jual beli secara online tercantum dalam KUHPerdata. Pengaturan dalam KUHPerdata ini dijadikan sebagai dasar hukum yang secara formal yuridis diakui keabsahannya. Pada awalnya diatur tentang syarat sahnya suatu perjanjian. Dimana syarat sahnya suatu perjanjian itu tercantum dalam ketentuan Pasal 1320 KUHPerdata, sedangkan pasal ini menentukan bahwa adanya syarat subyektif dan syarat objektif. Dalam subyektifnya ditentukan, yang mengadakan perjanjian tersebut adalah pihak yang dengan harus adanya kata sepakat dan cakap. Sedangkan dalam syarat obyektif ditentukan bahwa adanya keharusan dari suatu hal tertentu dan adanya suatu sebab yang diperbolehkan. Batas usia cakap untuk melakukan perbuatan hukum berdasarkan undang-undang adalah berbeda. Selanjutnya, mengenai batasan usia cakap menurut KUH Perdata adalah 21 tahun, sedangkan Undang-Undang No.2 Tahun 2014 tentang Perubahan Atas Undang-Undang Nomor 30 Tahun 2004 tentang Jabatan Notaris dan Undang-Undang No.13 Tahun 2003 tentang Ketenagakerjaan cakap adalah telah berumur 18 tahun. Sedangkan akibat hukum perjanjian sah apabila memenuhi syarat subyektif dan obyektif sebagaimana yang tercantum dalam ketentuan Pasal 1320 KUH Perdata. ${ }^{7}$ Pengaturan batas usia dalam suatu perjanjian tersebut sangat penting karena menentukan tingkat kesadaran seseorang dalam membuat kesepakatan atau usia tersebut menentukan tingkat kematangan seseorang dalam menentukan atau membuat keputusan untuk mengadakan kesepakatan.

Kecakapan termasuk kedalam syarat subyektif "apabila suatu perjanjian tidak memenuhi syarat subyektif maka akibat hukum dapat dibatalkan". 8 Terkait dengan kecakapan, maka dalam melakukan suatu peristiwa para pihak mengadakan jual beli dalam bentuk perjanjian. Pelanggaran terhadap para pihak atau pelaku jual beli online yang salah satu pihaknya belum cakap berbuat hukum atau belum berumur 21 tahun maka akibat hukumnya perjanjian itu batal demi hukum atau dapat dibatalkan (vernietigbaar, voidable) karena tidak terpenuhinya syarat subjektif dalam Pasal 1320 KUH Perdata yaitu syarat kedua kecakapan dalam berbuat hukum. ${ }^{9}$ Dalam arti lain, kecakapan itu juga diartikan bahwa seseorang tersebut tidak berada dibawah pengampuan atau dalam kondisi keterbelakangan mental. Apabila seseorang tersebut berada dibawah pengampuan, maka oleh undang-undang dianggap tidak mampu mengadakan perjanjian atau kesepakatan. Perjanjian tersebut menurut hukum tidak sah. Perjanjian semacam itu oleh hukum dapat dibatalkan.

Sehubungan dengan Pasal 1320 KUHPerdata tersebut, maka "dalam ketentuan Pasal 1313 KUHPerdata menentukan bahwa perjanjian adalah perbuatan dengan mana satu orang atau lebih mengikatkan dirinya terhadap seorang atau lebih". Hal tersebut kemudian menimbulkan peristiwa berupa perikatan yang didalamnya terdapat hubungan hukum berupa hak dan kaewajiban dari pihak masing-masing. Pasal 1457 sampai Pasal 1540 KUH Perdata mengatur mengenai jual beli, yang

7 Suadnyani, Ni Nyoman Endi, Darmadi, AA. Sagung Wiratni dan Westra, I Ketut, "Kecakapan Berdasarkan Batasan Usia Dalam Membuat Perjanjian Dihadapan Notaris", Kertha Semaya: Journal Ilmu Hukum 5, No.1 (2017): 5.

8 Bumi, Shinta Vinayanti dan Indrawati, Anak Agung Sri. “Syarat Subjektif Sahnya Perjanjian Menurut Kitab Undang-Undang Hukum Perdata (Kuh Perdata) Dikaitkan Dengan Perjanjian E-Commerce", Kertha Semaya: Journal Ilmu Hukum 1, No.3 (2013): 5.

9 Wicaksono, Bima Bagus dan Kasih, Desak Putu Dewi. "Implementasi Syarat Kecakapan Dalam Perjanjian Jual Beli Online”, Kertha Semaya: Journal Ilmu Hukum 6, No.10 (2018): 7. 
diartikan "sebagai suatu persetujuan antara pihak satu dengan pihak lainnya, yang mana mereka mengikatkan diri untuk menyerahkan sebuah barang sedangkan pihak lainnya diwajibkan membayar barang tersebut sesuai dengan yang telah diperjanjikan". Sehingga perjanjian jual beli adalah "suatu perbuatan seorang atau lebih terhadap seorang atau lebih mengikatkan dirinya untuk menyerahkan suatu barang dan pihak yang satu membayar harga yang dijanjikan". ${ }^{10}$ Pasal selanjutnya yaitu 1458 menjelaskan bahwa "jual beli dianggap telah terjadi antara kedua belah pihak, segera setelah orang-orang itu mencapai kesepakatan tentang barang tersebut beserta harganya, meskipun barang itu belum diserahkan dan harganya belum dibayar".

Secara konsep, perjanjian itu dibuat atas dasar kebersamaan atau persetujuan bersama antar para pihak. Sehubungan dengan konsep tersebut, sesuai dengan asas konsensualisme, setelah tercapainya suatu kesepakatan antara kedua belah pihak mengenai hal-hal pokok yang berkaitan dengan objek perjanjian maka detik itu juga suatu perjanjian lahir. Dibuatnya suatu perjanjian juga didasarkan atas kecakapan dari pihak-pihak yang membuatnya. Kecakapan merupakan suatu kemampuan untuk melakukan perbuatan hukum yang berkaitan dengan objek perjanjian. Hal tersebut dimaksudkan agar suatu objek perjanjian itu harus jelas ditentukan oleh para pihak. Objek perjanjian harus diperhitungkan jenis dan jumblahnya serta tidak digunakan untuk kepentingan umum. Adanya suatu sebab yang halal artinya adalah dalam suatu perjanjian isinya tidak boleh bertentangan dengan peraturan perundang-undangan, kesusilaan, ketertiban umum.

Sehubungan terhadap pengaturan jual beli yang diatur dalam ketentuan KUHPerdata tersebut, pengaturan jual beli juga diatur dalam ketentuan Pasal 5 UU ITE. Ketentuan pasal ini menyatakan bahwa informasi, dokumen dan tanda tangan elektronik dapat sebagai bukti yang sah dalam bertransaksi e-commerce dianggap sah sepanjang informasi yang tercantum didalamnya dapat diakses, ditampilkan, dijamin keutuhannya dan dapat dipertanggungjawabkan sehingga menerangkan suatu keadaan. Menurut Asser dalam perjanjian terdiri dari bagian inti (essensialia) dan bagian bukan inti (naturalia) dan (accidentalia). ${ }^{11}$ Tiap-tiap bagian tersebut merupakan unsur-unsur yang wajib dipenuhi dalam mengadakan suatu perjanjian. Unsur essensialia merupakan unsur yang mutlak harus ada perjanjian. Berkaitan erat dengan syarat sahnya perjanjian pada Pasal 1320 KUH Perdata dan untuk mengetahui ada atau tidaknya perjanjian serta untuk mengetahui jenis perjanjiannya, sebagai contoh yaitu kesepakatan. Selanjutnya unsur naturalia, merupakan unsur yang lazimnya ada atau merupakan sifat bawaan perjanjian, sehingga secara diam-diam melekat pada perjanjian, misalnya menjamin terhadap cacad tersembunyi terhadap barang yang diperjual belikan, sedangkan unsur accidentalia merupakan unsur yang harus tegas diperjanjikan, misalnya alamat pengiriman barang dan alat pembayaran apa yang dipergunakan. ${ }^{12}$

10 Sinaga, Liberty dan Jaya, I.B Surya Dharma. "Pembatalan Perjanjian Jual Beli Online Secara Sepihak Oleh Lazada.co.id (Studi Kasus)", Kertha Semaya: Journal Ilmu Hukum 2, No.6 (2014): 3.

11 Dharma, Anak Agung Gde Siddhi Satrya, Sarjana, I Made dan Indrawati, Anak Agung Sri. "Kajian Yuridis Keabsahan Jual Beli Secara Elektronik (E-Commerce) Dengan Menggunakan Kartu Kredit", Kertha Semaya: Journal Ilmu Hukum 1, No.05 (2013): 5-6.

12 Badrulzaman, Mariam Darus. KUHPerdata Buku III (Bandung, Alumni, 2006), 99. 
Pengaturan lebih lanjut tercantum dalam ketentuan Pasal 6 UU ITE. Pasal ini,menentukan bahwa dalam hal terdapat ketentuan lain selain yang diatur dalam Pasal 5 ayat (4) yang mensyaratkan bahwa suatu informasi harus berbentuk tertulis atau asli, informasi elektronik dan/atau dokumen elektronik dianggap sah sepanjang yang tercantum informasi didalamnya dapat ditampilkan,diakses, serta dijamin keutuhannya dan dapat dipertanggungjawabkan sehingga menerangkan suatu keadaan. Ketentuan ini mengharuskan adanya informasi yang berbentuk tertulis serta dapat dijamin keasliannya. Selain itu, dokumen elektronik tersebut dianggap sah menurut hukum apabila informasi tersebut dapat diakses, ditampilkan, dijamin keutuhannya dan dapat dipertanggungjawabkan. ${ }^{13}$ Jadi pada intinya, ketentuan ini mewajibkan adanya informasi yang dapat memberikan keterangan yang jelas terhadap suatu keadaan baik mengenai keberadaan pihak yang bersangkutan maupun objek atau dokumen yang diperjanjikan. Dengan demikian, maka perjanjian jual beli yang didakan secara online itu wajib adanya bentuk yang tertulis serta dapat diakses, dijamin keutuhan serta dapat dipertanggung jawabkan terhadap sesuatu dan keadaan tertentu. Pengaturan dalam pasal ini sangat penting dan sangat memberikan kekuatan dalam substansi perjanjian, maka akan adanya penguat tersebut, maka apa yang telah disepakati itu otomatis memiliki kekuatan hukum atau kekuatan yang diberikan oleh undang-undang bersifat khusus tersebut.

\subsection{Penerapan Asas Konsensualisme Dalam Perjanjian Jual Beli Online}

Sebutan aspek dalam jurnal ilmiah ini diartikan sebagai sudut pandang. Oleh sebab penelitian ini mengkaji penerapan asas konsensualisme dalam perjanjian jual beli secara online, maka perjanjian jual beli secara online tersebut dikaji dengan menggunakan sudut pandang hukum dalam hukum perdata. Sudut pandang hukum yang digunakan untuk mengkaji perjanjian tersebut yaitu sudut pandang yang didasarkan pada perjanjian secara online. Peraturan perundang-undnagan yang terkait dengan yakni KUHPerdata dan informasi dan transaksi elektronik. Kedua peraturan itu dipakai dasar kajian atau sebagai sudut pandang terhadap isu-isu hukum khususnya berkaitan dengan isu hukum penerapan asas konsensualisme dalam perjanjian jual beli online.

Asas konsensualisme atau konsensus ini memiliki bentuk. Bentuk tersebut merupakan bentuk yang dianggap sah oleh KUHPerdata. Sedangkan perjanjian jual beli secara online juga memiliki bentuk yang tertulis. Bentuk tertulis dalam perjanjian secara online ini dianggap sah oleh ketentuan UU ITE. Dalam hukum perjanjian di Indonesia, "perjanjian jual beli tersebut apabila ditinjau melalui hukum perjanjian yang bersumber pada KUHPerdata adalah sah karena telah memenuhi syarat yang diharuskan baik syarat obyektif maupun syarat subyektif, maka sebagaimana halnya jual beli pada umumnya (konvensional), ${ }^{14}$. Kesepakatan di dalam adanya perjanjian jual beli online haruslah dilakukan dengan memenuhi asas itikad baik dan berbagai asas-asas berkontrak. Selain itu, para pihak juga membubuhkan tanda tangan pada perjanjian itu. Dalam "tanda tangan itu juga menjadi dasar sahnya suatu perjanjian. seseorang yang memberikan tanda tangannya pada sebuah dokumen perjanjian meskipun yang bersangkutan hanya mengetahui sebagian atau seluruh dari isi

13 Dharma, Anak Agung Gde Siddhi Satrya, Sarjana, I Made dan Indrawati, Anak Agung Sri, Op.cit., h.7.

14 Purwahadi A, "Telaah Singkat Tentang Undang-Undang Perlindungan Konsumen." Jurnal Hukum dan Keadilan 3, No.3 (2000): 9-10. 
dokumen perjanjian yang telah disepakati dan ditandatangani bersama sehingga yang bersangkutan akan terikat dengan janji sesuai dengan isi dari perjanjian yang disepakati. ${ }^{15}$

Asas dijadikan acuan dalam dibuatnya perjanjian, tidak hanya ada satu asas tapi ada beberapa asas antara lain asas kebebasan berkontrak, asas kepastian hukum, asas konsensulisme, asas pactasunt servenda, asas itikad baik, asas kepribadian. Sebagai salah satu contohnya yaitu asas kebebasan berkontrak dimana dalam penerapanya diberikan kebebasan untuk menentukan dengan siapa perjanjian tersebutdibuat perjanjian, seperti apa bentuknya serta isinya, ${ }^{16}$ serta bisa diberikan kebebasan dalam pengaturan terhadap apa saja yang menjadi muatan atau juga substansi perjanjian sepanjang tidak boleh semua hal bertenangan. Perjanjian dapat dijadikan seperti 'undang-undang'untuk pihak yang telibat serta jika oleh kehendaknyasendiri,sebagaiman telah dimuat dalam ketentuan Pasal 1388 ayat (1) KUH Perdata, selain itu terdapat asas itikad baik yang juga dapat diperlukan untuk memperkuat adanya kekuatan mengikat, sehingga akan adanya kepercayaan yang dapat meningka diantara para pihak karena telah menguntungkan atau tidak saling merugikan para pihak. ${ }^{17}$

Asas beritikad yang baik adalah suatu asas yang sangat fundamental dalam membuat suatu perjanjian. Itikad baik dalam pelaksanaan perjanjian, termasuk perjanjian secara online yaitu asas itikad baik haruslah dipahami dan diterapkan dengan sebaik-baiknya oleh para pihak guna mencegah terjadinya wanprestasi didalam pelaksanaan perjanjian secara online. ${ }^{18}$ Sedangkan asas konsensualisme merupakan suatu kesepakatan dalam perjanjian, pada dasarnya merupakan perwujudan dari kehendak dua pihak atau lebih dalam perjanjian tersebut, mengenai hal-hal yang mereka kehendaki untuk dilaksanakan, mengenai tata cara melaksanakannya, mengenai saat pelaksanaannya dan mengenai pihak yang berkewajiban untuk melaksanakan hal-hal yang telah disepakati tersebut. ${ }^{19}$ Dalam kespakatan juga terdapat perikatan. Perikatan yang dimaksudkan adalah sebuah hubungan hukum antara dua orang atau dua pihak berdasarkan salah satu pihak berhak menuntut sesuatu hal dari pihak yang lain dan pihak yang lain berkewajiban untuk memenuhi tuntutan itu sesuai denganperjanjian. ${ }^{20}$ Sebagaimana diuraikan pada pengertian perjanjian yaitu suatu perbuatan dengan mana satu orang atau lebih mengikatkan dirinya terhadap satu orang lain atau lebih. ${ }^{21}$ Obyek

15 Nitisuari, I Gusti Ayu Agung Diyah dan Purwanto, I Wayan Novy. "Klausula Eksonerasi Dalam Perjanjian Pengangkutan Barang", Kertha Semaya: Journal Ilmu Hukum 8, No.4 (2020): 7.

16 Egarini, Putu Wahyu Ning dan Sarjana, I Made. "Problematika Memorandum of Understanding (MoU) Dalam Hukum Perjanjian Indonesia", Kertha Semaya: Journal Ilmu Hukum 8, No.4 (2020): 7-8.

17 Ari Putra, Gede Nopta; Priyanto, I Made Dedy (2020). Asas Itikad Baik Dalam Memperkuat Kekuatan Mengikat Memorandum Of Understanding. Kertha Semaya: Journal Ilmu Hukum 8, No.3 (2020): 14.

18 Wijaya, I Gede Krisna Wahyu dan Dananjaya Nyoman Satyayudha. "Penerapan Asas Itikad Baik Dalam Perjanjian Jual Beli Online", Kertha Semaya: Journal Ilmu Hukum 6, No. 8 (2018): 4.

19 Ibid.

20 Ibid.

21 Scolastika, Sheanny dan Darmadha, I Nyoman. "Penyelesaian Wanprestasi Dalam Hubungan Kontraktual (Studi Kaus Putusan No. 44/PID/2018/PT.DPS)", Kertha Semaya: Journal Ilmu Hukum 7, No.4 (2019): 11. 
perjanjian berupa prestasi yaitu suatu kewajiban yang harus dipenuhi dan/atau dilaksanakan oleh para pihak sesuai dengan apa yang diperjanjikan.

Suatu perjanjian, baik tertulis maupun online itu bersifat mengikat dan berlaku bagi para pihaknya ketika jual beli tersebut disepakati oleh kedua belah pihak, hal ini terjadi dikarenakan adanya sifat terbuka dari KUHPerdata, sedangkan asas-asas dalam KUHPerdata yang dapat digunakan dalam perjanjian secara online, diantaranya yaitu asas Kebebasan Berkontrak (Contractorijheid). ${ }^{22}$ Ketentuan Pasal 1338 ayat (1) KUHPerdata menyatakan "bahwa semua perjanjian yang dibuat secara sah berlaku sebagai undang-undang bagi mereka yang membuatnya". Sehubungan perjanjian yang dengan dilakukan secara online, perjanjian secara online itu berlaku kepada yang telah bersepakat. Bentuk inilah yang dinamakan dengan konsensus. Istilah konsensus ini merupakan suatu kesepakatan bersama. Mengenai hal-hal yang telah disepakati itu dituangkan kedalam perjanjian dan sebagai substansi dari perjanjian yang dibentuk.

Berkaitan dengan perjanjian yang dilakukan secara online ini juga wajib menggunakan asas-asas atau asas-asas hukum. Hal ini, asas hukum yang digunakan yaitu asas hukum terutama berkaitan dengan perjanjian. Seperti halnya konsep konsensus atau disebut dengan persesuaian kehendak. Istilah "semua" yang menunjukkan diberinya kesempatan terhadap setiap orang untuk menyatakan keinginannya yang dirasa baik dalam membuat suatu perjanjian, terdapat dalam ketentuan Pasal 1338 KUH Perdata. Selain itu juga suatu perjanjian harus dilaksanakan dengan itikad baik. Pasal ini menekankan adanya asas itikad baik ini yang kemudian diteruskan dengan asas konsensualisme yang dituangkan kesebuah janji. Selanjutnya, didalam asas kepercayaan (Vertrouwensbeginsel), dimana seseorang yang mengadakan perjanjian dengan pihak lain, menumbuhkan kepercayaan antara kedua belah pihak. Penekanan asas ini yakni, perjanjian tidak mungkin ada tanpa adanya kepercayaan antar pihak satu dengan pihak lainnya. Para pihak akan merasakan adanya keraguan dan ketidaknyamanan tanpa adanya sebuah kepercayaan, sehingga akan menimbukan tidak ada kekuatan mengikat. Asas Kekuatan Mengikat (Pucta Sunt Servanda) Terikatnya para pihak dalam suatu perjanjian dapat kita lihat dalam Pasal 1338 ayat (1) KUHPerdata. Dalam perjanjian secara online, jika terjadi kesepakatan maka akan timbul kewajiban hukum yang tidak dapat dihindari oleh adanya para pihak karena mengikat sifatnya.

Kepastian Hukum dalam perjanjian, sebagai figur hukum harus mengandung hukum. Hukum yang dimaksudkan dlaam suatu perjanjian tersebut merupakan suatu bentuk manifestasi adanya kepastian hukum. Oleh karena itu, setiap perjanjian dibuat secara tertulis agar diperoleh suatu kekuatan hukum, sehingga tujuan kepastian hukum dapat terwujud. ${ }^{23}$ Kepastian hukum merupakan konsekuensi dari adanya asas yang lain. Asas keseimbangan, asas ini menghendaki kedua belah pihak memenuhi dan melaksanakan perjanjian yaitu melaksanakan kewajiban masing-masing untuk memperoleh hak sebagai konsekuensinya. ${ }^{24}$

Jual-Beli secara online dari sudut pandang hukum perjanjian di Indonesia menggunakan Pasal 18 ayat (1) UU Informasi dan Transaksi Elektronik yang dituangkan kedalam Kontrak Elektronik mengikat para pihak. Daya ikat yang

22 Dharma, Anak Agung Gde Siddhi Satrya, Sarjana, I Made Sarjana dan Indrawati, Anak Agung Sri, Op.cit, h. 12.

23 Warmadewa, I Made Aditia dan Udiana, I Made. "Akibat Hukum Wanprestasi Dalam Perjanjian Baku", Kertha Semaya: Journal Ilmu Hukum 5, No.2 (2017): 2.

24 Wijaya, I Gede Krisna Wahyu dan Dananjaya, Nyoman Satyayudha, Op.cit., 8. 
tertuang didalam sebuah kontrak elektronik mengikat para pihak, jika dilihat dari ketentuan Pasal 18 ayat (1) tersebut, yang mana perjanjian transaksi elektronik suatu kontrak elektronik yang dilakukan melalui perjanjian tersebut tetaplah perjanjian sebagaimana perjanjian konvensional yang mengikat para pihak serta melahirkan hak dan kewajiban bagi para pihak. ${ }^{25}$

\section{Kesimpulan}

Pengaturan perjanjian melalui media online, diatur dalam ketentuan Pasal 1320 KUHPerdata dan juga Pasal 1313 KUHPerdata sebagai dasar hukum dari suatu perjanjian secara online. Keabsahan jual-beli secara online dimana para pihak yang mengadakan perjanjian dapat menerapkan KUHPerdata sebagai dasar diakui keabsahannya dimana syarat sahnya perjanjian tercantum dalam Pasal 1320 KUHPerdata dan Pasal 5, Pasal 6 dan Pasal 18 ayat (1) UU ITE menentukan bahwa informasi, dokumen dan tanda tangan elektronik dapat sebagai bukti yang sah dalam bertransaksi secara online. Dengan adanya ketentuan tersebut, maka dapat dijamin adanya kepastian hukum dalam perjanjian jual beli melalui media online.

Penerapan asas konsensalisme yaitu didasarkan pada hukum perdata, khususnya dengan mendasarkan pada hukum perjanjian yang juga bersumber pada KUHPerdata. Penerapan asas konsensualisme ini adalah asas yang sangat fundamental dalam teknis pembuatan perjanjian secara online. Penerapannya harus didasarkan pada dua belah pihak atau lebih dan didasarkan pada kesepakatan. Kesepakatan tersebut adalah syarat dikatakan sah oleh hukum karena telah memenuhi syarat yang diharuskan baik syarat obyektif maupun syarat subyektif. Jual-Beli secara online menurut hukum perjanjian mendasarkan pada Pasal 18 ayat (1) UU ITE yang dituangkan ke dalam Kontrak Elektronik yang mengikat para pihak.

\section{DAFTAR PUSTAKA}

\section{Buku}

Badrulzaman, Mariam Darus. KUHPerdata Buku III (Bandung, Alumni, 2006).

Marzuki, Peter Mahmud. Penelitian Hukum (Jakarta, Predana Media Group, 2010).

Susnato, Hapy. Konsumen Hak-Hak Dirugkan, (Yogyakarta, Media Visi, 2008).

Wiradipradja, E.S dan Budhijanto, D. Perspektif Hukum Internasional tentang Cyber Law, dalam Kantaatmadja, et al, Cyberlaw : Suatu Pengantar (Jakarta, Elips 11, 2002).

\section{Jurnal Hukum}

Ari Putra, Gede Nopta; Priyanto, I Made Dedy (2020). “Asas Itikad Baik Dalam Memperkuat Kekuatan Mengikat Memorandum Of Understanding", Kertha Semaya: Journal Ilmu Hukum 8, No.3 (2020).

Bumi, Shinta Vinayanti dan Indrawati, Anak Agung Sri. "Syarat Subjektif Sahnya Perjanjian Menurut Kitab Undang-Undang Hukum Perdata (Kuh Perdata) Dikaitkan Dengan Perjanjian E-Commerce", Kertha Semaya: Journal Ilmu Hukum 1, No.3 (2013).

${ }^{25}$ Wijaya, I Gede Krisna Wahyu dan Dananjaya, Nyoman Satyayudha, Op.cit. 
Dharma, Anak Agung Gde Siddhi Satrya, Sarjana, I Made dan Indrawati, Anak Agung Sri. “Kajian Yuridis Keabsahan Jual Beli Secara Elektronik (E-Commerce) Dengan Menggunakan Kartu Kredit", Kertha Semaya: Journal Ilmu Hukum 01, No.05 (2013).

Egarini, Putu Wahyu Ning dan Sarjana, I Made. "Problematika Memorandum of Understanding (MoU) Dalam Hukum Perjanjian Indonesia", Kertha Semaya: Journal Ilmu Hukum 8, No.4 (2020).

Mahardika, Putu Surya dan Rudy, Dewa Gede. “Tanggung Jawab Pemilik Toko Online Dalam Jual Beli Online (E-Commerce) Ditinjau Berdasarkan Hukum Perlindungan Konsumen", Kertha Semaya: Journal Ilmu Hukum 02, No.05 (2014).

Manika, Ni Putu Mella dan Sukihana, Ida Ayu. "Perlindungan Hukum Terhadap Subjek dalam Potret yang Diunggah ke Akun Media Sosial", Kertha Semaya: Journal Ilmu Hukum 6, No.12 (2018): 10.

Nitisuari, I Gusti Ayu Agung Diyah dan Purwanto, I Wayan Novy. "Klausula Eksonerasi Dalam Perjanjian Pengangkutan Barang", Kertha Semaya: Journal Ilmu Hukum 8, No.4 (2020).

Purwahadi A, "Telaah Singkat Tentang Undang-Undang Perlindungan Konsumen." Jurnal Hukum dan Keadilan, Volume 3 Nomor 3 (2000).

Scolastika, Sheanny dan Darmadha, I Nyoman. "Penyelesaian Wanprestasi Dalam Hubungan Kontraktual (Studi Kaus Putusan No. 44/PID/2018/PT.DPS)”, Kertha Semaya: Journal Ilmu Hukum 7, No.4 (2019).

Sinaga, Liberty dan Jaya, I.B Surya Dharma. “Pembatalan Perjanjian Jual Beli Online Secara Sepihak Oleh Lazada.co.id (Studi Kasus)", Kertha Semaya: Journal Ilmu Hukum 02, No.06 (2014).

Suadnyani, Ni Nyoman Endi, Darmadi, AA. Sagung Wiratni dan Westra, I Ketut, "Kecakapan Berdasarkan Batasan Usia Dalam Membuat Perjanjian Dihadapan Notaris", Kertha Semaya: Journal Ilmu Hukum 5, No.1 (2017).

Warmadewa, I Made Aditia dan Udiana, I Made. "Akibat Hukum Wanprestasi Dalam Perjanjian Baku", Kertha Semaya: Journal Ilmu Hukum 5, No.2 (2017).

Wicaksono, Bima Bagus dan Kasih, Desak Putu Dewi. “Implementasi Syarat

Kecakapan Dalam Perjanjian Jual Beli Online", Kertha Semaya: Journal Ilmu Hukum 6, No.10 (2018).

Wijaya, I Gede Krisna Wahyu dan Dananjaya Nyoman Satyayudha. “Penerapan Asas Itikad Baik Dalam Perjanjian Jual Beli Online", Kertha Semaya: Journal Ilmu Hukum 6, No. 8 (2018).

\section{Peraturan Perundang-undangan}

Undang-undang Dasar Negara Republik Indonesia Tahun 1945.

Kitab Undang-Undang Hukum Perdata, Burgerlijk Wetboek, 2004, diterjemahkan oleh R.

Subekti dan R. Tjitrosudibio, Pradnya Paramita, Jakarta.

Undang-Undang Nomor 8 Tahun 2011 tentang Informasi dan Transaksi Elektronik. 